\title{
Renin and angiotensinogen expression and functions in growth and apoptosis of human glioblastoma
}

\author{
L Juillerat-Jeanneret', ', J Celerier ${ }^{2}, C$ Chapuis Bernasconi' ${ }^{1}, G$ Nguyen $^{3}$, W Wostl ${ }^{4}$, HP Maerki ${ }^{4}$, \\ R-C Janzer', P Corvol ${ }^{2}$ and J-M Gasc ${ }^{2}$
}

'University Institute of Pathology, CHUV, Bugnon 25, Lausanne CHIOII, Switzerland; ${ }^{2}$ INSERM U36, Collège de France, 10 place M. Berthelot, Paris F75005, France; ${ }^{3}$ NSERM U489, Hôpital Tenon, 4 rue de la Chine, Paris F75020, France; ${ }^{4}$ Hoffmann-La Roche Ltd, Pharmaceuticals Division, Basel CH 4070, Switzerland

\begin{abstract}
The expression and function in growth and apoptosis of the renin-angiotensin system (RAS) was evaluated in human glioblastoma. Renin and angiotensinogen (AGT) mRNAs and proteins were found by in situ hybridisation and immunohistochemistry in glioblastoma cells. Angiotensinogen was present in glioblastoma cystic fluids. Thus, human glioblastoma cells produce renin and AGT and secrete AGT. Human glioblastoma and glioblastoma cells expressed renin, AGT, renin receptor, $A T_{2}$ and/or $A T_{1}$ mRNAs and proteins determined by RT-PCR and/or Western blotting, respectively. The function of the RAS in glioblastoma was studied using human glioblastoma cells in culture. Angiotensinogen, des(Ang I)AGT, tetradecapaptide renin substrate (AGTI - I4), Ang I, Ang II or Ang III, added to glioblastoma cells in culture, did not modulate their proliferation, survival or death. Angiotensin-converting enzyme inhibitors did not diminish glioblastoma cell proliferation. However, the addition of selective synthetic renin inhibitors to glioblastoma cells decreased DNA synthesis and viable tumour cell number, and induced apoptosis. This effect was not counterbalanced by concomitant addition of Ang II. In conclusion, the complete RAS is expressed by human glioblastomas and glioblastoma cells in culture. Inhibition of renin in glioblastoma cells may be a potential approach to control glioblastoma cell proliferation and survival, and glioblastoma progression in combination therapy.

British Journal of Cancer (2004) 90, 1059 - 1068. doi:I0.1038/sj.bjc.6601646 www.bjcancer.com

(c) 2004 Cancer Research UK
\end{abstract}

Keywords: renin; angiotensinogen; glioblastoma; renin inhibitors; apoptosis; human

In addition to their functions in controlling vascular tone and natriohydric balance, the components of the renin-angiotensin system (RAS) may be involved in cell growth and survival. Angiotensin peptides may promote cell growth, whereas angiotensinogen (AGT) was shown to inhibit vascular cell growth and angiogenesis (Célérier et al, 2002). These functions may be of particular importance in human disorders related to growth dysfunctions, either increased proliferation such as cardiovascular remodelling and cancer, or diminished proliferation such as defects in tissue repair.

The RAS is composed of a precursor molecule, AGT, a peptide related to the family of serine protease inhibitors (serpins), as the unique substrate for the protease renin (EC 3.4.23.15). The hydrolysis of AGT by renin is rate-limiting for the whole system and results in the production of $\operatorname{des}$ (Ang I)-AGT and of the vasoinactive peptide Ang I, which is converted to the vasoactive peptides Ang II and Ang III by angiotensin-converting enzyme (ACE) (EC 3.4.15.1) and aminopeptidase A (EC 3.4.11.7), respectively. These peptides act on two membrane-bound receptors $\left(\mathrm{AT}_{1}\right.$ and $\left.\mathrm{AT}_{2}\right)$ belonging to the seven-transmembrane $\mathrm{G}$ -

\footnotetext{
*Correspondence: Dr L Juillerat-Jeanneret;

E-mail: lucienne.juillerat@chuv.hospvd.ch

Received 3 September 2003; revised 5 December 2003; accepted 15 December 2003
}

protein-coupled receptor (GPCR) family. More recently, it has been suggested that, in addition to the release of Ang I from AGT, renin might act directly on cell function as a ligand for a cellmembrane receptor, resulting in the phosphorylation of ERK (extracellular regulated kinase) (Takahashi et al, 1985; Nguyen et al, 1996, 2002). Inhibitors of the renin and ACE enzymes as well as antagonists to the $\mathrm{AT}_{1}$ receptors have been developed in the context of cardiovascular disorders.

The RAS is expressed independently of the circulating RAS in normal nonvascular tissues (Inwang et al, 1997; Tahmasebi et al, 1998; Hirasawa et al, 2002), including the CNS (Milsted et al, 1990; Humpel et al, 1994), where, in addition to regulating cardiovascular functions (Morimoto et al, 2002), its role may include the control of cell death and/or growth (Kakinuma et al, 1997). Reninsecreting tumours of several nonrenal origins have been described and the role of the RAS has been evaluated in a few situations in human cancer. In breast cancer, Ang II increased integrin expression (Berry et al, 2001) and Ang II exerted growthpromoting effects via the $\mathrm{AT}_{1}$ receptor (De Paepe et al, 2001). In a C6 glioblastoma rat model, losartan ( $\mathrm{AT}_{1}$ antagonist) reduced tumour growth, vascular density, cell proliferation and mitotic index (Rivera et al, 2001). We have previously shown high expression of ACE protein in human glioblastoma vessels; however, inhibition of ACE did not modify the growth of an experimental glioblastoma implanted in rat brains (JuilleratJeanneret et al, 2000). The production of renin and AGT or a 
potential function of renin, angiotensins and/or AGT in these tumours was not evaluated in these previous experiments. Therefore, in the present study, we report the expression and functions of renin, AGT and angiotensin peptides in human glioblastoma tumours and human glioblastoma cells in culture.

\section{MATERIAL AND METHODS}

\section{Human surgical specimens}

Human astrocytoma and glioblastoma samples (grade II, $n=1$, grade III, $n=6$; grade IV, $n=5$ ) were retrospectively selected from surgical diagnostic biopsies or subtotal resection specimens, either fixed in $4 \%$ buffered paraformaldehyde and embedded in paraffin, or frozen in liquid nitrogen and stored at $-80^{\circ} \mathrm{C}$. Paraffinembedded samples were used for immunohistochemistry and in situ hybridisation and frozen samples for Western blotting and RT - PCR experiments. The fluid content of glioblastoma pseudocysts (due to the absence of epithelial lining, the term cyst cannot be used formally) was obtained at the time of surgery by aspiration of the fluid, and stored at $-80^{\circ} \mathrm{C}$. Plasma was obtained from patients with various diseases and cerebrospinal fluids were retrospectively selected from patients with brain tumours undergoing punctions for diagnostic purposes.

\section{Immunohistochemistry}

Paraffin-embedded sections ( $5 \mu \mathrm{m}$ thick) of human glioblastoma were deparaffinised in xylene and isopropanol, and endogenous peroxidase was inactivated in 3\% hydrogen peroxide in methanol. Sections were incubated with the antirenin 2D12/F37 and 4G1/F55 monoclonal antibodies, as previously described (Galen et al, 1984; Juillerat-Jeanneret et al, 2000), anti-AGT (N-1345 and C-1350 (Célérier et al, 2000)), anti-des(Ang I)-AGT (D854 (Célérier et al, 2000)), and subsequently exposed to peroxidase-conjugated secondary immunoglobulins. Peroxidase activity was visualised using $0.035 \%$ diaminobenzidine (Fluka) as a chromogen, and slides were counterstained with haematoxylin.

\section{In situ hybridisation}

In situ hybridisation for renin, ACE and AGT was performed essentially as previously described (Sibony et al, 1995). Briefly, paraffin sections $(7 \mu \mathrm{m})$ were deparaffinised, rehydrated, heated in a microwave oven, and digested with proteinase $\mathrm{K}$ (Roche Diagnostics) before hybridisation with the ${ }^{35}$ S-labelled riboprobes $\left(3-4 \times 10^{5} \mathrm{cpm} \mathrm{section}^{-1}\right)$. Hybridisation was performed overnight at $50^{\circ} \mathrm{C}$ and was followed by several washes and an RNAse treatment to remove single-strand nonhybridised cRNA strands. Sense probes were used as controls. Sections were exposed in the dark, processed for autoradiography and counterstained with toluidine blue. Observation was performed under dark field or bright field illumination.

\section{AGT concentration measurements}

The concentration of AGT in glioblastoma ascitic fluids was determined by measuring the production of Ang I concentrations at $37^{\circ} \mathrm{C}$ in the absence or presence of added renin, as previously described (Célérier et al, 2002). AGT equivalents were calculated from the Ang I generated from AGT present in the ascitic fluid.

\section{RT - PCR and Western blotting determination of the components of the RAS}

Total RNA was isolated from cells in culture or from surgical samples using the Trizol reagent (Gibco-BRL, Basel, Switzerland). $\mathrm{RT}-\mathrm{PCR}$ was performed according to standard procedures and 35 cycles, using primer sequences given in Table 1. Positive controls were mRNAs extracted from normal human kidney, liver, pulmonary artery or breast cancer. As controls for RNA quality, amplification reactions were performed using pairs of primers specific for glyceraldehyde-3-phosphate dehydrogenase (GAPDH; Egidy et al, 2000). Amplified transcripts were analysed on $2 \%$ agarose gels.

Proteins were extracted from confluent layers of glioblastoma cell cultures in $40 \mathrm{~mm}$ HEPES pH 7.5 containing $100 \mathrm{~mm} \mathrm{NaCl}$, $0.1 \mathrm{mM}$ EDTA, $100 \mathrm{~mm}$ PMSF, $10 \%$ glycerol, $0.5 \%$ NP40, and the extracts were submitted to electrophoresis. After transfer, the membranes were probed using the F37 antirenin monoclonal antibody (Galen et al, 1984), a kind gift of Sanofi-Pasteur, Montpellier, polyclonal antirenin-receptor antibody (Nguyen et al, 2002), polyclonal anti- $\mathrm{AT}_{1}$ and anti-AT $\mathrm{A}_{2}$ (Santa-Cruz Biotechnologies, Santa-Cruz, CA, USA) antibodies, and revealed using the ECL detection kit (Amersham, UK).

\section{Treatments of glioblastoma cell cultures}

Human recombinant AGT or des(Ang I)AGT were obtained from AGT-transfected CHO-cell supernatants, as previously described (Célérier et al, 2002). CHO cells were grown in serum-free medium (Célérier et al, 2000) and secreted $15 \mathrm{mg}$ AGT per litre of medium in $24 \mathrm{~h}$. Mock-transfected cell supernatants were used as controls. Experiments were performed in the presence or absence of FasLcontaining Neuro2A cell supernatants, as previously described (Egidy et al, 2000; Peduto Eberl et al, 2000). Human renin

Table I Specific primers for the amplification of renin, renin receptor, angiotensinogen, $A T_{1}$ and $A T_{2}$

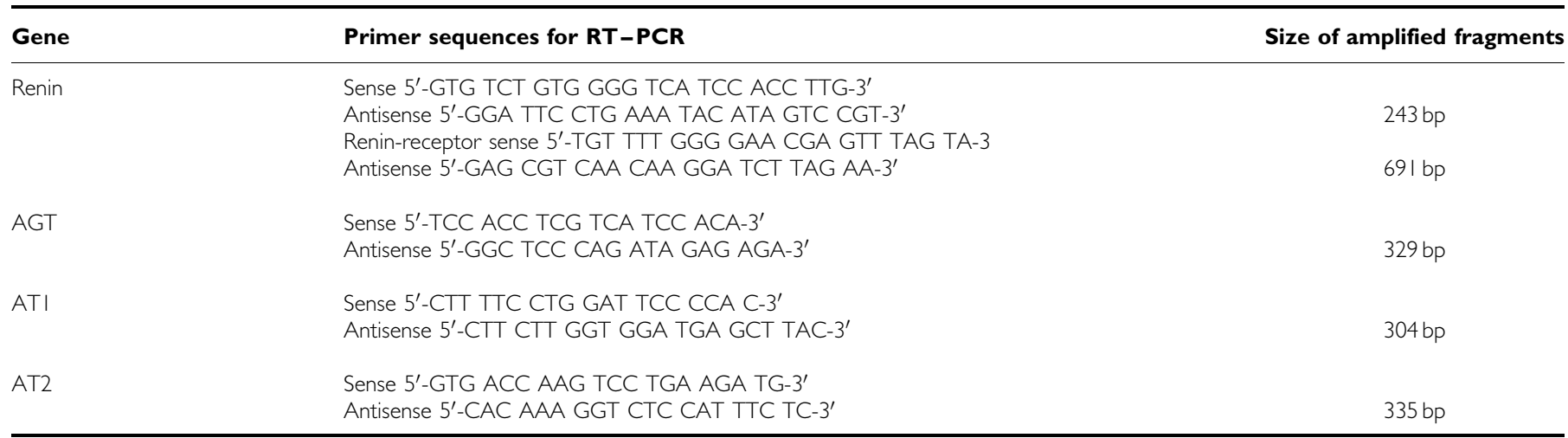

AGT: angiotensinogen; AT: angiotensin receptor. 
tetradecapeptide substrate (AGT1-14), Ang I, Ang II or Ang III were purchased from Bachem (Bubendorf, Switzerland) and dissolved in $\mathrm{H}_{2} \mathrm{O}$. Pepstatin was purchased from Fluka (Buchs, Switzerland) and dissolved in methanol. Remikiren (Fischli et al, $1991)$ and $(R)-3-[(3 S, 4 R, 5 R)-4$-[4-[3-(2-methoxy-benzyloxy)-propoxy]-phenyl]-5-(4-methoxy-naphthalen-2-ylmethoxy)-piperidin3-ylmethoxy]-propane-1,2-diol (RO0663525\} (Breu et al, 2000) were provided by Hoffmann-LaRoche (Basel, Switzerland). Stock solution of Remikiren was prepared in $\mathrm{H}_{2} \mathrm{O}$ and of $\mathrm{RO} 0663525$ in methanol, and then diluted in cell culture medium. The ACE inhibitors captopril (Sigma, Buchs, Switzerland) and lisinopril (a gift from Merck, Sharp and Dohme; Juillerat-Jeanneret, 1993) were dissolved at $10 \mathrm{mg} \mathrm{ml}^{-1}$ and diluted in culture medium. The $\mathrm{AT}_{2}$ antagonist PD123319 was purchased from Sigma. LN18 and LNZ308 human glioblastoma cells (a kind gift of AC Diserens, CHUV, Lausanne, Switzerland; Diserens et al, 1981) were grown in DMEM medium containing $4.5 \mathrm{gl}^{-1}$ glucose and 5\% FCS. Cells were split in 48-well plates and cultured for 1-3 days until confluence was reached. Peptides or inhibitors were added to the cells in culture for the time and concentration indicated. Then either 3-(4,5-dimethyl-2-thiazolyl)-2,5-diphenyl-2H-tetrazoliumbromide (MTT) reduction (cf below) to quantify the number of metabolically active viable cells, thymidine incorporation (cf below) to quantify DNA synthesis or measurement of nucleosome fragments to quantify apoptosis, were performed (cf below). Experiments were performed in triplicates at least three times and means \pm s.d. were calculated.

\section{Evaluation of cell viability, growth and apoptosis}

The following techniques were performed as previously described: cell viability was determined using MTT (Sigma, Buchs, Switzerland) reduction and absorbance at $540 \mathrm{~nm}$; DNA synthesis using $\left[{ }^{3} \mathrm{H}\right]$-thymidine $\left(0.2 \mu \mathrm{Ci}_{\text {well }}{ }^{-1}\right.$; Amersham Pharmacia, Dübendorf, Switzerland) incorporation (Egidy et al, 2000) and apoptosis was quantified using the Cell Death Detection ELISA ${ }^{\text {PLUS }}$ (Roche, Rotkreuz, Switzerland), as previously described (Peduto Eberl et al, 2000).

\section{Protein concentration}

Protein content was evaluated with the BCA protein assay kit (Pierce, Switzerland) according to the manufacturer's instructions, using bovine serum albumin as standard.

\section{RESULTS}

RT-PCR performed on three different glioblastoma surgical specimens demonstrated a heterogenous expression of the RAS components in human glioblastoma. All the three tumours expressed the mRNAs for renin receptor, $\mathrm{AGT}$ and $\mathrm{AT}_{1}$ (two at low level for this last molecule), two out of three expressed renin mRNA and one out of three $\mathrm{AT}_{2}$ mRNA (Figure 1). The cellular localisation of AGT, renin and ACE synthesis in human glioblastoma was determined by in situ hybridisation (ISH) and immunohistochemistry (IHC) (Figure 2). AGT mRNA and protein were expressed by nontumoral astrocytes and glioblastoma cells (Figure 2A-F). Renin mRNA and protein were highly expressed by nontumoral neurons (Figure $2 \mathrm{G}-\mathrm{I}$ ), macrophages (not shown; Juillerat-Jeanneret et $a l, 2000)$ and at a lower level by reactive astrocytes (not shown), and were nonhomogeneously expressed by tumour cells (Figure 2J-L). High ACE mRNA expression was found in tumour vessels (Figure 2Q, R), confirming our previous observation of a high expression of ACE protein in glioblastoma vasculature by immunohistochemistry (Juillerat-Jeanneret et al, 2000 ), but only at a very low level in the vessels of nontumoral

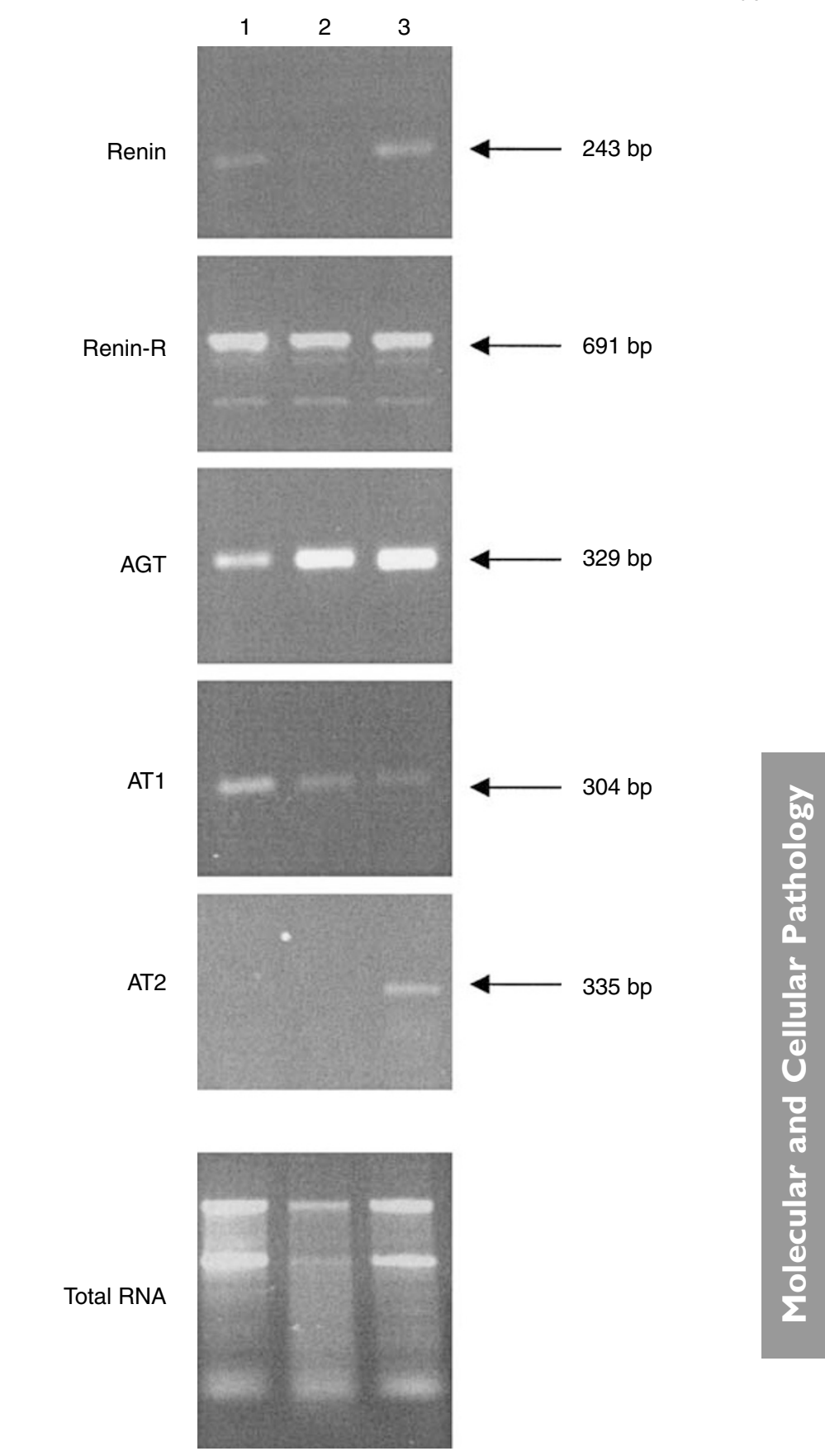

Figure I Determination of renin, renin receptor, $A G T, A T_{1}$ and $A T_{2}$ mRNAs by RT-PCR performed in three human glioblastoma surgical samples. RNA extracted from three human glioblastomas was used for RT-PCR analysis for renin, renin receptor (renin-R), AGT and angiotensin receptors (AT, and $A T_{2}$ ), using the specific primers described in Table 1 .

tissue (Figure $2 \mathrm{~N}, \mathrm{O}$ ). ACE protein was found in tumour-associated and non-tumoral vessels (Figure $2 \mathrm{M}, \mathrm{P}$ ).

In order to ascertain whether AGT was secreted by human tumours, its level was determined in human glioblastomaassociated pseudocyst fluid withdrawn at the time of surgery (Table 2). For the purpose of comparison, AGT in human cerebrospinal fluids (CSF) from various brain tumour patients $\left(n=13, \quad 0.17 \pm 0.10 \mu \mathrm{g} \quad \mathrm{AGT}\right.$ equivalent $\mathrm{ml}^{-1}, \quad 0.23 \pm 0.12 \mu \mathrm{g}$ $\mathrm{AGT} \mathrm{mg}^{-1}$ protein) and in human plasma $(n=12,226.0 \pm 62.3 \mu \mathrm{g}$ AGT equivalent $\mathrm{ml}^{-1}, 3.23 \pm 1.22 \mu \mathrm{g} \mathrm{AGT} \mathrm{mg}^{-1}$ protein) was also 

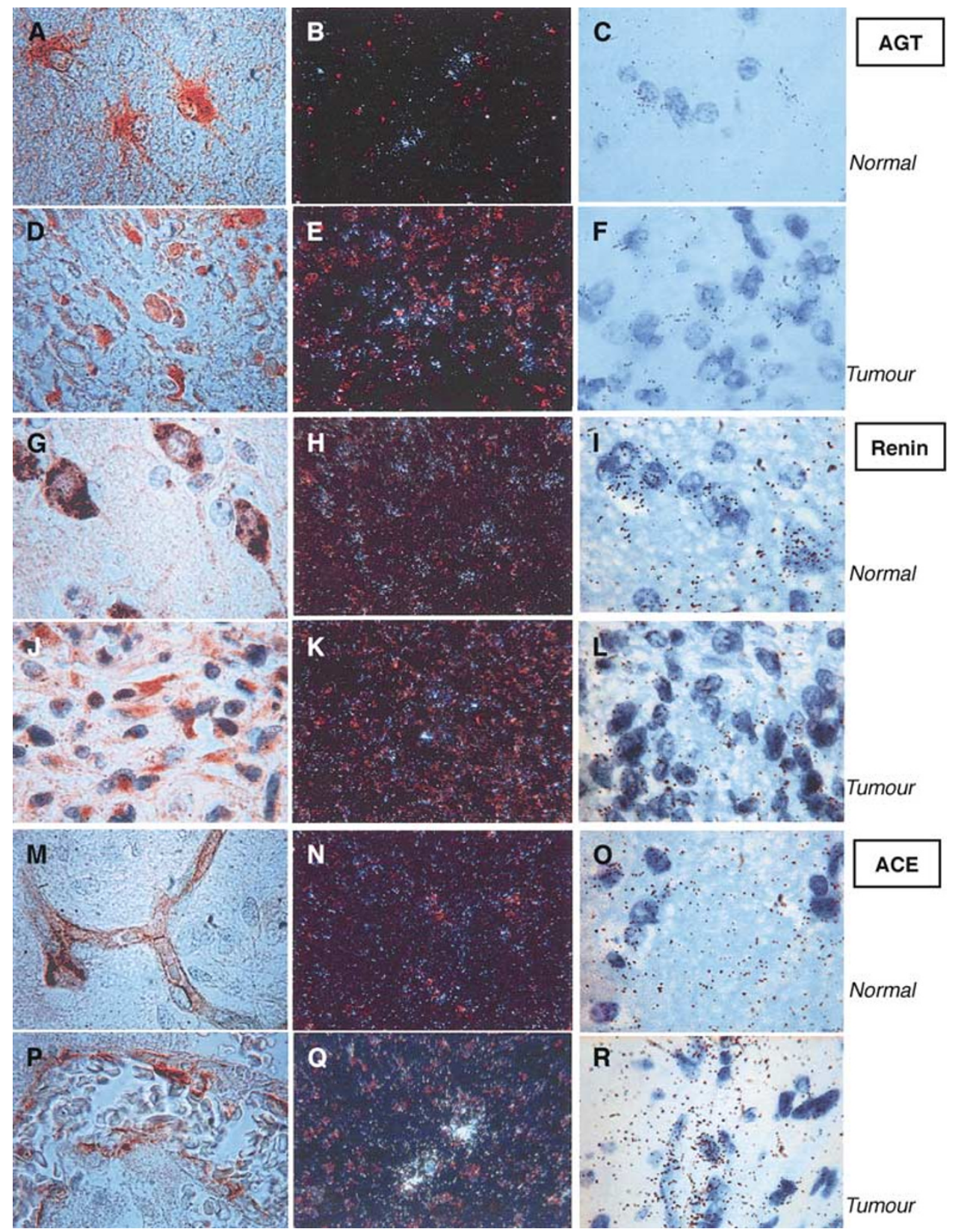

Figure $2 \mathrm{ISH}$ and immunohistochemistry for renin, ACE and AGT in human glioblastoma and nontumoral associated tissue. Angiotensinogen (AGT) $(\mathbf{A}-\mathbf{F})$, renin $(\mathbf{G}-\mathbf{L})$ and angiotensin-converting enzyme (ACE) $(\mathbf{M}-\mathbf{R})$ expression in human glioblastoma (grade IV) $(\mathbf{D}-\mathbf{F}, \mathbf{J}-\mathbf{L}, \mathbf{P}-\mathbf{R})$ and nontumoral associated tissue $(\mathbf{A}-\mathbf{C}, \mathbf{G}-\mathbf{I}, \mathbf{M}-\mathbf{O})$. In situ hybridisation (ISH) (B, C, E, F, H, I, K, L, N, O, Q, R) was performed with the antisense probes for AGT, renin or ACE, and immunohistochemistry $(\mathbf{A}, \mathbf{D}, \mathbf{G}, \mathbf{J}, \mathbf{M}, \mathbf{P})$ with antibodies raised against human $\mathrm{AGT}$, renin or ACE. Dark-field $(\mathbf{B}, \mathbf{E}, \mathbf{H}, \mathbf{K}, \mathbf{N}, \mathbf{Q})$ or bright-field illumination of the same tumour areas in consecutive slides. Sense probes or nonrelevant antibodies did not display any signal (not shown)

measured. The approach used allowed to quantify Ang I release from AGT in the presence of added renin and protease inhibitors to preclude further degradation of Ang I. The results showed that AGT, but not renin, was present in pseudocyst fluid at concentrations lower than circulating levels but higher than in CSF. However, the ratio of AGT to total proteins was much higher in the plasma than in pseudocyst fluid, suggesting that the AGT in pseudocyst does not result from simple diffusion from plasma. Thus, the information obtained using these approaches indicated that the upstream components of the RAS are expressed in tumour cells of human glioblastoma.

Having established the presence of most of the RAS components in human glioblastoma, we addressed its role in tumour cells using the human LN18 and LNZ308 glioblastoma cell lines (Diserens et al, 1981; Egidy et al, 2000; Juillerat-Jeanneret et al, 2000). Both cell lines expressed renin, renin receptor, $A G T$ and $A_{2}$ mRNAs using RT-PCR, while only LNZ308 expressed $\mathrm{AT}_{1}$ mRNA (Figure $3 \mathrm{~A}$ ). Using Western blotting, renin (mainly produced as prorenin), renin receptor and $\mathrm{AT}_{2}$ proteins were expressed in both cell lines, while only $\mathrm{LNZ308}$ cells expressed $\mathrm{AT}_{1}$ protein, corresponding to mRNA expression (Figure 3B). We had previously shown using an IRMA immunoassay (Juillerat-Jeanneret $e t a l, 2000)$ that renin protein can be measured in cell extracts of human glioblastoma cells, but not in the culture supernatants. We have also previously shown that ACE activity is not measurable in glioblastoma cells in culture (Juillerat-Jeanneret et al, 2000). 
Together, these results suggest that human glioblastoma cells have the potential to produce AGT, prorenin/renin and Ang I, but not to convert Ang I into Ang II.

To address the functions of the RAS in human glioblastoma, we first evaluated the effect of inhibiting renin and ACE in glioblastoma cells. Three renin inhibitors, pepstatin, remikiren and RO0663525, at increasing concentrations were used to evaluate for the functions of renin in glioblastoma cells. While pepstatin and remikiren had little effect on glioblastoma cells, the addition of the RO0663525 synthetic renin inhibitor to tumour cells abolished DNA synthesis after $9 \mathrm{~h}$ or $24 \mathrm{~h}$ (Figure 4) (Figure $5 \mathrm{~A}$ ), as well as decreased the number of viable tumour cells after $24 \mathrm{~h}$ (Figure $5 \mathrm{~A}$ ). The presence of FCS did not modify glioblastoma cell response to the renin inhibitors (Figure 5B). The effect of the RO0663525 renin inhibitor on DNA synthesis was rapid, since identical inhibition was obtained after 2 or $8 \mathrm{~h}$ exposure, indicating that new protein synthesis was not necessary to obtain this effect (Figure 6). RO0663525 renin inhibitor induced apoptosis in glioblastoma cells after $9 \mathrm{~h}$ exposure, but only in cells previously deprived of FCS for $24 \mathrm{~h}$ (Figure 7A and B). The ACE inhibitors captopril and lisinopril did not modulate cell proliferation after 24 or $48 \mathrm{~h}$ (results not shown).

Then, we evaluated whether the production of angiotensin peptides was involved in glioblastoma cell growth, survival and/or apoptosis. Neither AGT nor Ang II modulated glioblastoma cell growth, as determined by thymidine incorporation to quantitate DNA synthesis and MTT reduction to quantitate metabolically active cells (Figure 8A). Tetradecapeptide renin substrate (TDP/ AGT1-14), Ang I or Ang III comparably to Ang II, even at high concentration, did not modulate thymidine incorporation

Table 2 Quantification of angiotensinogen in human glioblastoma pseudocyst

\begin{tabular}{|c|c|c|c|}
\hline Sample & Protein $\left(\mathrm{mg} \mathrm{ml}^{-1}\right)$ & AGT equivalent ( $\mu \mathrm{g}$ Ang $\mathrm{Iml}^{-1}$ ) & Specific activity ( $\mu \mathrm{g}$ AGT $\mathrm{mg}^{-1}$ prot) \\
\hline A-4II & 59.5 & 4.2 & 0.07 \\
\hline Gbl-747 & 53.3 & 4.2 & 0.08 \\
\hline Gbl-749 & 50.8 & 6.1 & 0.12 \\
\hline Gbl-859 & 52.8 & 4.7 & 0.09 \\
\hline Gbl-920 & 39.5 & 4.7 & 0.11 \\
\hline Gbl-988 & 59.7 & 5.2 & 0.09 \\
\hline Cystic fluids $(n=6)$ & $52.6 \pm 7.4$ & $4.9 \pm 0.7$ & $0.09 \pm 0.02$ \\
\hline
\end{tabular}

A: astrocytome grade II; Gbl: glioblastoma. Pseudocystic fluids $(n=6)$ were incubated in the presence of added renin and Ang I produced was measured at the end of the incubation period, providing equivalent AGT. Mean \pm s.d. values of the combined samples were calculated.
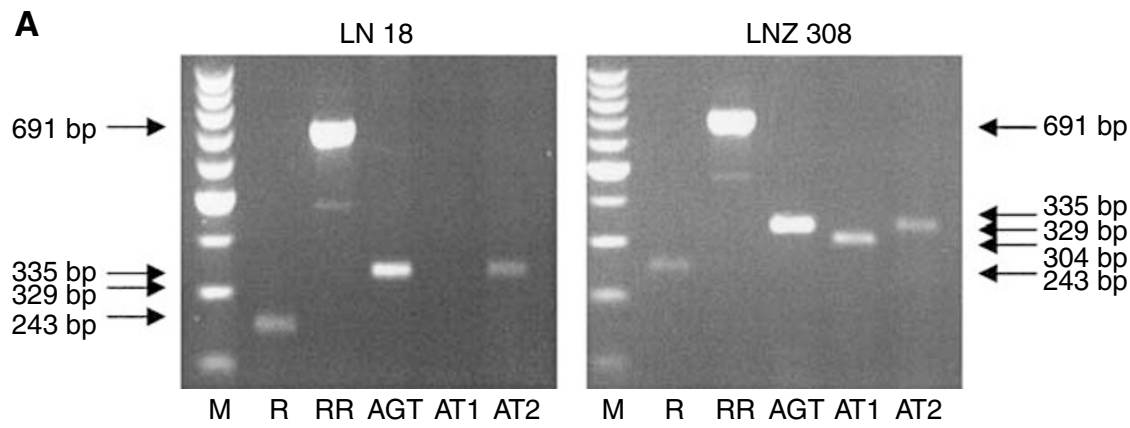

B
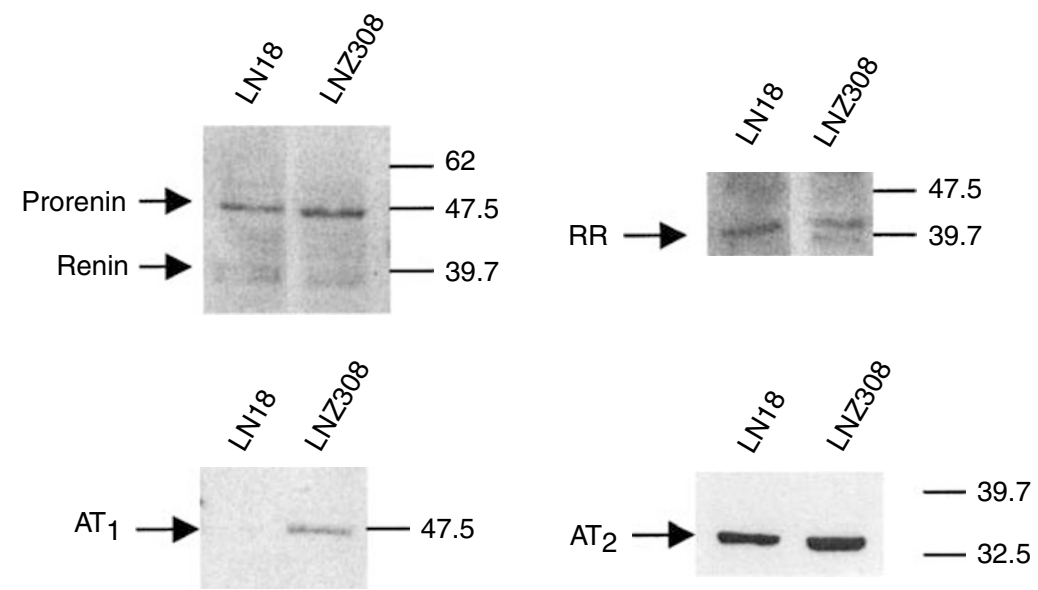

Figure 3 Determination of renin, renin receptor, AGT, AT, and AT 2 in human LNI 8 and LNZ308 glioblastoma cells. (A) RNA extracted from human glioblastoma cell lines were used for RT - PCR amplification of renin (R), renin receptor (RR), AGT and angiotensin receptor (AT, and $A T_{2}$ ) $m R N A s$, using the specific primers described in Table I. (B) Proteins extracted from human glioblastoma cell lines were used for Western blotting analysis of the expression of renin, $R R, A T_{1}$ and $A T_{2}$ proteins. 
A
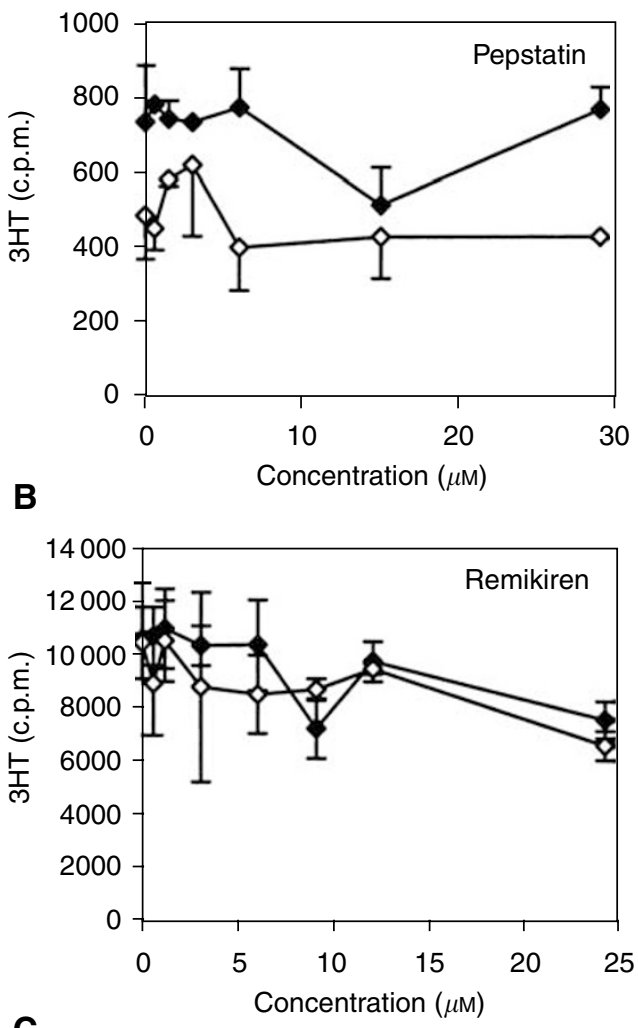

C

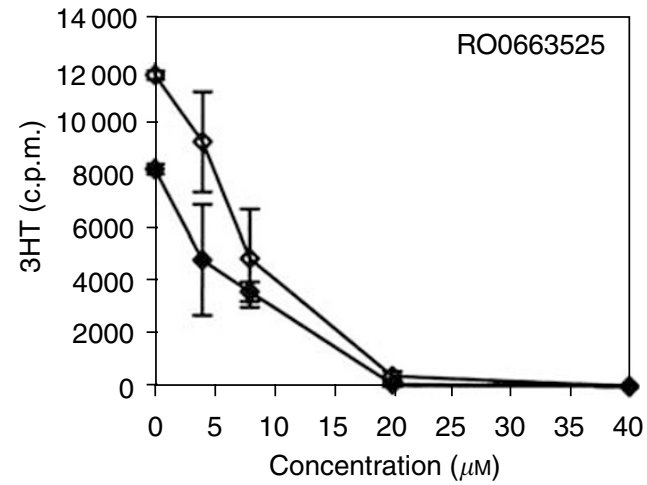

Figure 4 Renin inhibitors selectively decrease DNA synthesis in human glioblastoma cells. Cells were grown to confluence in culture medium containing FCS, then exposed for $24 \mathrm{~h}$ to different renin inhibitors at increasing concentrations in fresh medium containing FCS. ${ }^{3} \mathrm{H}$-thymidine $\left({ }^{3} \mathrm{HT}\right)$ incorporation to quantify DNA synthesis was performed during the two last hours of incubation. (A) Pepstatin; (B) remikiren; (C) R00663525. : LNI8 cells; $\diamond:$ LNZ308 cells. Means \pm s.d. were calculated.

(Figure 8B). AGT did not induce apoptosis or sensitise LN18 and LNZ308 cells to FasL-induced apoptosis (Table 3). We had previously shown (Egidy et al, 2000) that LN18 cells are sensitive to FasL-induced apoptosis, while LNZ308 cells needs sensitisation to undergo FasL-induced apoptosis. Thus, neither AGT, renin, TDP, Ang I, nor Ang II, the active hormone of the systemic RAS, nor Ang III, the predominant peptide produced in human glioblastoma (Juillerat-Jeanneret et al, 2000), are important in directly regulating glioblastoma cell growth and/or controlling apoptosis. Addition of the $\mathrm{AT}_{2}$ antagonist PD123319 to glioblastoma cells expressing this receptor did not modify DNA synthesis (results not shown). Exogenous addition of Ang II or $\mathrm{AT}_{1}$ or $\mathrm{AT}_{2}$ receptor antagonists together with renin inhibitors either did not counterbalance the growth-inhibitory effects RO0663525 or did not potentiate Remikiren effects (results not shown). Thus, the active molecule of the RAS in glioblastoma cells is the enzyme prorenin/ renin, independently of the binding of angiotensin peptides to their cell-membrane receptors.

\section{DISCUSSION}

The expression of renin, AGT, $\mathrm{ACE}$ and $\mathrm{AT}_{1}$ receptor in the developing and normal brain has been previously described. In normal brain, the main cells expressing AGT are mostly astrocytes (Humpel et al, 1994), while renin is expressed both by astrocytes and neuron populations. However, most information has been obtained in rodents. Renin expression has been previously demonstrated by immunohistochemistry in human glioblastoma (Ariza et al, 1988) and AGT synthesis by Northern blotting in nontumoral $(n=3)$ and tumoral $(n=3)$ astrocytic cell lines (Milsted et al, 1990). In this small series, AGT expression was higher in normal than tumoral cells, with heterogenous expression between cells. No expression of renin or ACE was found. ACE is ubiquitously expressed by the vascular system including brain vasculature. We have previously shown that human glioblastoma cell lines did not express ACE activity, but that ACE is highly expressed in the abnormal vessels of human glioblastoma (Juillerat-Jeanneret et al, 2000). From this information, it was postulated that a complete angiotensin system existed in the brain, independently of the circulating system, and it was assumed that its role, including in tumours, was important in the regulation of vascular functions. In the vasculature, AGT, the unique and specific substrate of renin, was demonstrated to be antiangiogenic (Célérier et al, 2000, 2002), while angiotensin peptides, in particular Ang II, were shown to be proangiogenic and to be involved in vascular growth (Rivera et al, 2001). However, no study has directly questioned the functions of the RAS, and of its components, in tumoral astrocytes such as human glioblastoma cells.

In cancer, the role of the RAS has been mainly evaluated in the context of vascular functions (Achard et al, 2001). In a C6 glioblastoma rat model, losartan (an $\mathrm{AT}_{1}$ antagonist) reduced tumour growth, vascular density, tumour cell proliferation and mitotic index (Rivera et al, 2001). In the present study, we demonstrate that AGT, prorenin, $\mathrm{ACE}, \mathrm{AT}_{1}$ and $\mathrm{AT}_{2}$ are synthesised and expressed in human glioblastoma and glioblastoma cells in culture, however at different levels of expression between the specimens. Glioblastoma are highly heterogeneous tumours. Our results suggest that the expression of the RAS components varies according to the particular glioblastoma and/or tumour area, and thus reflects the clonal heterogeneity of glioblastoma. AGT is released in the tumour pseudocyst in vivo in humans, and ACE is expressed by tumour-associated vasculature, suggesting a potential production of all RAS components in the tumour environment.

We addressed first the functions of the angiotensin peptides in glioblastoma cells. In order to exclude an indirect effect of Ang peptides transactivating other signaling pathways, we only studied the effects of these peptides for short time exposure. We showed that AGT, TDP renin substrate and Ang peptides did not play any role in glioblastoma cell growth, apoptosis and/or DNA synthesis. It may be hypothesised from previous information that their targets, if these peptides are produced by glioblastoma cells, is the tumour-associated vasculature. These effects involve $\mathrm{AT}_{1}$ receptors, while $\mathrm{AT}_{2}$ receptors may be growth inhibitory and proapoptotic (Berry et al, 2001). AGT and des(Ang I)-AGT have been shown to be anti-angiogenic (Célérier et al, 2002). Immunohistochemistry for AGT performed on normal tissue, and grade II and 
A
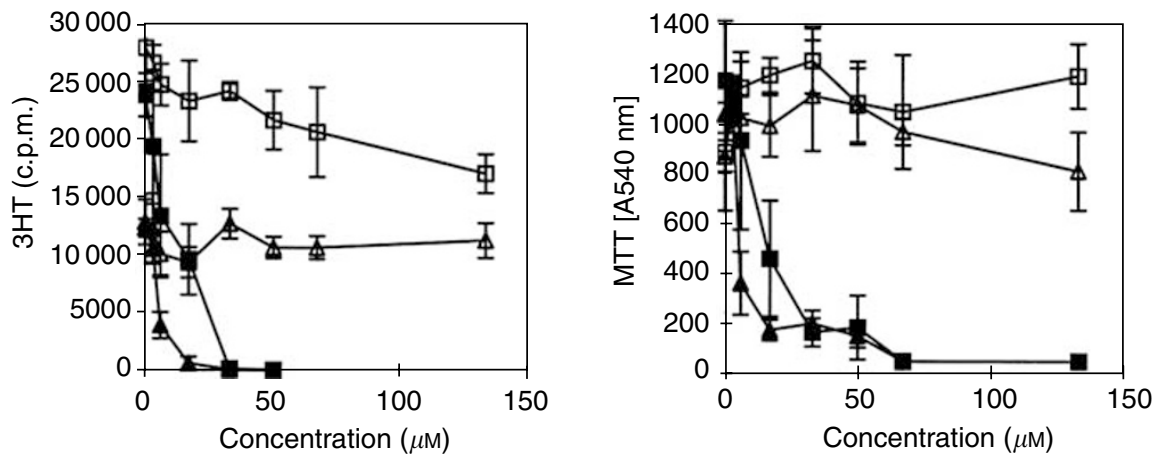

B
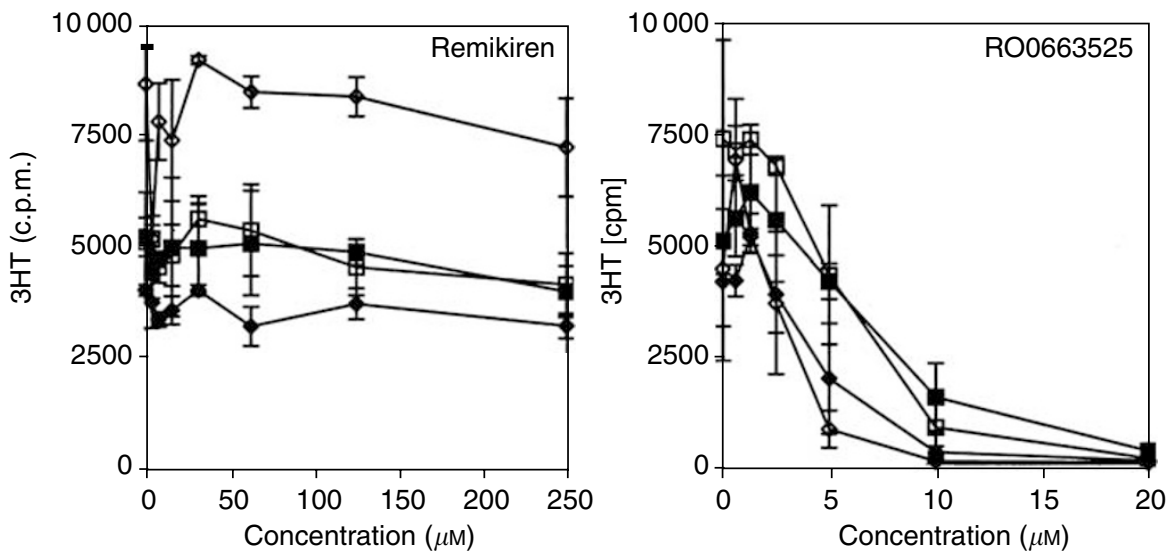

Figure 5 Exposure to RO0663525, but not to remikiren, results in inhibition of DNA synthesis and, concomitantly, a decrease of metabolically active viable glioblastoma cells. (A) Cells were grown to confluence in culture medium containing FCS, then exposed to renin inhibitors at increasing concentrations in fresh medium containing FCS either for $9 \mathrm{~h}$ and ${ }^{3} \mathrm{H}$-thymidine $\left({ }^{3} \mathrm{HT}\right)$ incorporation to quantify DNA synthesis was performed for the last two hours of incubation, or for $24 \mathrm{~h}$ and the number of metabolically active cells was determined using a MTT assay for the last two hours. LNI 8: $\mathbf{\Delta}$ RO0663525; $\triangle$ : remikiren; LNZ308: $\mathbf{\square}$ : RO0663525; $\square$ : remikiren. (B) Cells were grown to confluence in culture medium containing FCS, then either deprived of FCS for $24 \mathrm{~h}$ or maintained in FCS-containing medium, and exposed to Remikiren or RO0663525 renin inhibitors at increasing concentrations in fresh medium containing or not FCS for $9 \mathrm{~h}$ and ${ }^{3} \mathrm{H}$-thymidine $\left({ }^{3} \mathrm{HT}\right)$ incorporation to quantify DNA synthesis was performed for the last two hours of incubation. : LNI8 cells with FCS; $\diamond:$ LNZ308 cells no FCS; $\mathbf{0}$ : LNZ308 cells with FCS; $\square$ : LNZ308 cells no FCS.

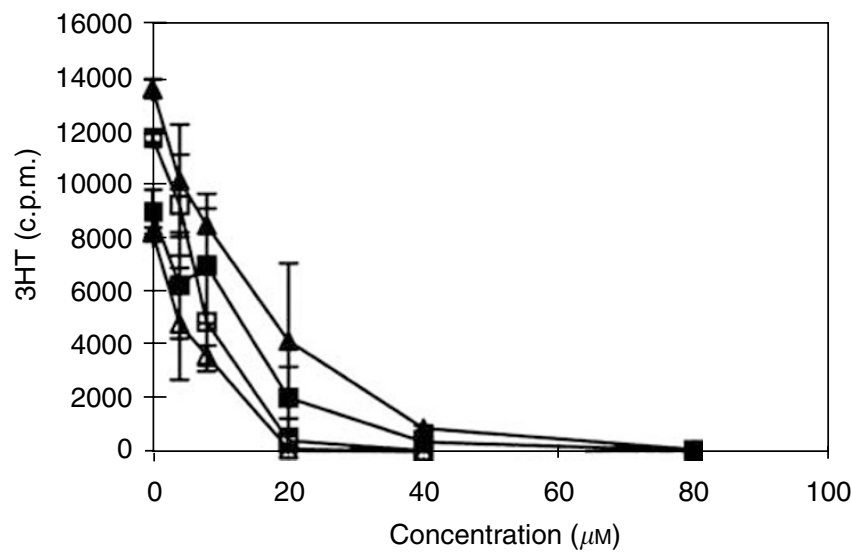

Figure 6 Inhibition of DNA synthesis by RO0663525 is an immediate effect. Cells were grown to confluence in culture medium containing FCS, then exposed for $2 \mathrm{~h}$ or $8 \mathrm{~h}$ to $\mathrm{RO} 0663525$ renin inhibitor at increasing concentrations in fresh medium containing FCS. ${ }^{3} \mathrm{H}$-thymidine $\left({ }^{3} \mathrm{HT}\right)$ incorporation to quantify DNA synthesis was performed during the last two hours of incubation. LNI8: $\mathbf{\Delta}: 2 \mathrm{~h} ; \triangle \mathrm{:}$ 8h; LNZ308: $\mathbf{\square}: 2 \mathrm{~h}, \square 8 \mathrm{~h}$. Means \pm s.d. were calculated.

III astrocytoma and glioblastoma multiform (grade IV) suggested that the expression of this protein was inversely related to tumour grading (manuscript in preparation).
We then addressed the effects of inhibiting the enzymes of the RAS in human glioblastoma. ACE inhibitors may be of some benefit in cancer (Nakagawa et al, 1995; Reddy et al, 1995; Lever et al, 1998; Yoshiji et al, 2002), mainly acting via their antiangiogenic potential and as more general zinc metalloprotease inhibitors, independently of the RAS and of ACE inhibition. Our previous experiments with lisinopril and experimental glioblastoma in the rat did not show any benefit in glioblastoma (JuilleratJeanneret et al, 2000); however, we cannot exclude that lisinopril was not transported across the cerebral vasculature (the bloodbrain barrier), which is not as leaky in experimental rodent models as in human glioblastoma. In the present study of human glioblastoma cells in culture, we did not show any effect of the ACE-inhibitors captopril and lisinopril in cancer cell growth and DNA synthesis, showing the specificity of ACE inhibitors between tumour cells of different origins.

However, one renin-selective inhibitor could induce a rapid and important blockade of DNA synthesis, apoptosis and loss of viable cells in human glioblastoma cells in culture. This effect of renin inhibitors seems to depend on the lipophilicity, efficacy $\left(\mathrm{IC}_{50} / K_{\mathrm{i}}\right)$ and chemical structure of the compounds, since RO0663525, a nonpeptidomimetic representative of the piperidine class of inhibitors (Güller et al, 1999; Oefner et al, 1999; Maerki et al, 2001), but not the more hydrophilic peptidomimetics remikiren and pepstatin, was efficient. Pepstatin is a better inhibitor of cathepsin D than of renin (Baldwin et al, 1993). Cathepsin D is more frequently expressed in carcinomas than in connective tissue 

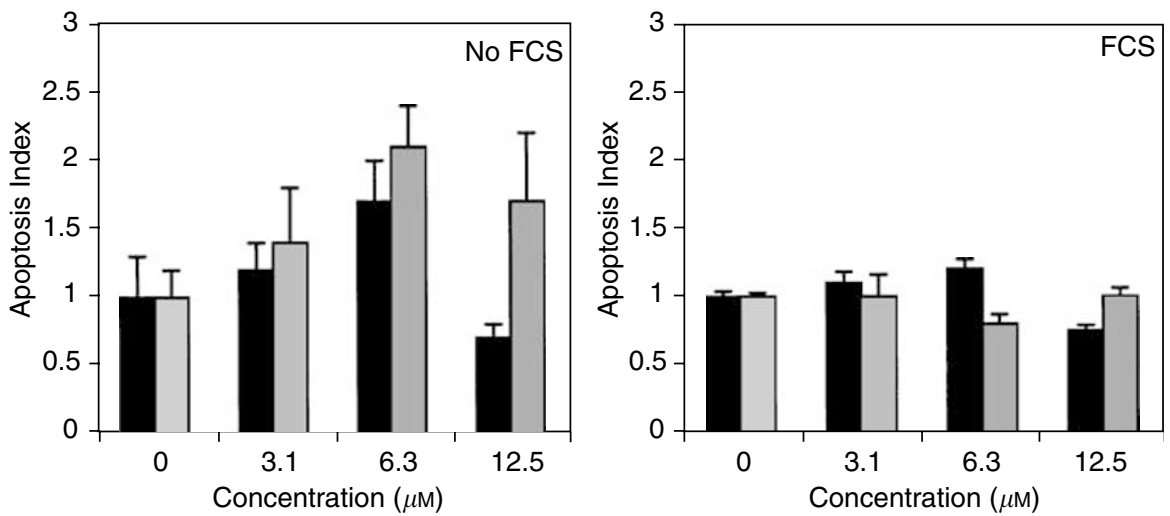

Figure 7 Induction of apoptosis by RO0663525. Cells were grown to confluence in culture medium containing FCS, then either deprived of FCS for $24 \mathrm{~h}$ (A) or maintained in medium with FCS (B), exposed for $9 \mathrm{~h}$ to RO0663525 renin inhibitor at increasing concentrations in fresh medium without FCS, and apoptosis index was determined by quantification of nucleosome fragments. Black bars: LN 18 cells; grey bars: LNZ308 cells. Means \pm s.d. were calculated.

Table 3 Angiotensinogen neither induces apoptosis, nor inhibits or sensitises glioblastoma cells to FasL-induced apoptosis

\begin{tabular}{|c|c|c|c|c|}
\hline \multirow{3}{*}{$\begin{array}{l}\text { Treatment } \\
\% \text { of CHO SN } \\
\left(\mu \mathrm{gAGT} \mathrm{ml}{ }^{-1}\right)\end{array}$} & \multicolumn{4}{|c|}{ Apoptosis index } \\
\hline & \multicolumn{2}{|c|}{ LNI 8} & \multicolumn{2}{|c|}{ LNZ308 } \\
\hline & No FasL & $2 \%$ FasL & No FasL & $2 \%$ FasL \\
\hline \multicolumn{5}{|l|}{ AGT-CHO cells } \\
\hline $0 \%\left(0 \mu \mathrm{g}\right.$ AGT mll $\left.{ }^{-1}\right)$ & 1.00 & 3.55 & 1.00 & 1.48 \\
\hline $1 \%\left(0.15 \mu \mathrm{g} \mathrm{m} l^{-1}\right)$ & 1.52 & 2.65 & 1.35 & 2.19 \\
\hline $5 \%\left(0.75 \mu \mathrm{g} \mathrm{ml}^{-1}\right)$ & 2.01 & 3.92 & 2.39 & 1.74 \\
\hline $10 \%\left(1.50 \mu \mathrm{g} \mathrm{ml}^{-1}\right)$ & 1.79 & 4.88 & 1.80 & 1.93 \\
\hline \multicolumn{5}{|l|}{ Mock-transfected-CHO cells } \\
\hline $0 \%$ & 1.00 & 3.55 & 1.00 & 1.48 \\
\hline $1 \%$ & 1.66 & 4.74 & 1.54 & 2.03 \\
\hline $5 \%$ & 1.91 & 5.38 & 0.96 & 1.92 \\
\hline $10 \%$ & 1.31 & 3.28 & 1.72 & 2.38 \\
\hline
\end{tabular}

AGT: angiotensinogen. LNI8 or LNZ308 cells were treated for $24 \mathrm{~h}$ in the absence of FCS either with $1-10 \%$ of angiotensinogen-containing supernatant of AGT-transfected $\mathrm{CHO}$ cells $\left(0-1.5 \mu \mathrm{g} \mathrm{AGT} \mathrm{ml}{ }^{-1}\right)$ or mock-transfected cells, or $2 \%$ of FasL-containing supernatant of Neuro2A-FasL cells or a combination of both. At the end of the incubation period, apoptosis index was quantified by measurement of nucleosome fragments in cells. Means of duplicate wells were calculated.

neoplasm such as glioblastoma (Reid et al, 1986); thus an inhibitory effect on cathepsin $\mathrm{D}$ can be excluded. We have previously shown that human glioblastoma cells do not secrete renin (Juillerat-Jeanneret et al, 2000). Thus, the inhibitory pattern of renin inhibitors suggests an intracellular function of prorenin/ renin, and thus only hydrophobic inhibitors have the potential to inhibit intracellular renin. It has been shown that an alternative transcription site for renin may be used in the brain, which would result, if transcribed, in the production of an altered form of prorenin mRNA, not secreted and constitutively active (Lee-Kirch et al, 1999; Sinn and Sigmund, 2000). Alternatively, it has been shown that the binding of piperidine inhibitors to the renin active site pocket results in an induced structural fit of the enzyme, which has not been demonstrated for peptidomimetic inhibitors (Deinum et al, 1998; Vieira et al, 1999; Maerki et al, 2001). This conformational change may modify the binding of renin/prorenin to its recently described renin receptor (Nguyen et al, 2002). We show here that human glioblastoma and glioblastoma cells in culture express and synthesise the renin receptor. This hormonelike function of renin/prorenin activates the intracellular signaling ERK pathways, and survival signalling. We have previously shown that endothelin receptor antagonists sensitise glioblastoma cells to Fas-L-induced apoptosis involving the ERK pathway and the regulation of anti/proapoptotic molecules (Egidy et al, 2000), raising the possibility of a comparable role for renin/reninreceptor functions, since we show here that RO0663525 can induce apoptosis in human glioblastoma cells.

In conclusion, our results suggest that the expression of the RAS in glioblastoma is heterogeneous and that its functions are double. First, AGT secreted by astrocytes, whether normal or tumoral cells, and neuron-derived and vascular-derived renin, ACE and aminopeptidases will produce angiotensin peptides (Ang I, Ang II, Ang III). It can be hypothesised from previous information that these peptides acting through angiotensin receptors on tumour-associated vasculature, regulate vascular functions and angiogenesis. Second, we have shown that renin has a direct role in glioblastoma cell proliferation and/or survival and that inhibitors of the enzyme induce a fast and important loss of proliferation and survival of glioblastoma cells, independent of the action of angiotensin peptides on their cognate receptors. Two models may explain this effect: (1) by inducing conformational changes, renin inhibitors abolish the function of renin on its receptor, activation of the receptor and intracellular survival signaling; (2) the functions of renin in glioblastoma cells may be intracellular, and do not involve cell-membrane-bound angiotensin receptors. These issues need to be resolved, but renin inhibition, in combination therapy with other drugs, may be a potential approach to control glioblastoma progression. 


\section{A}

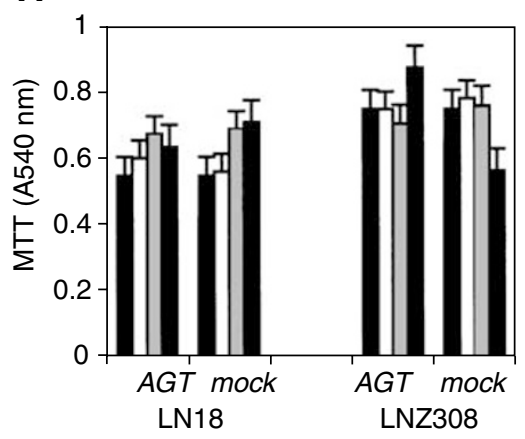

B
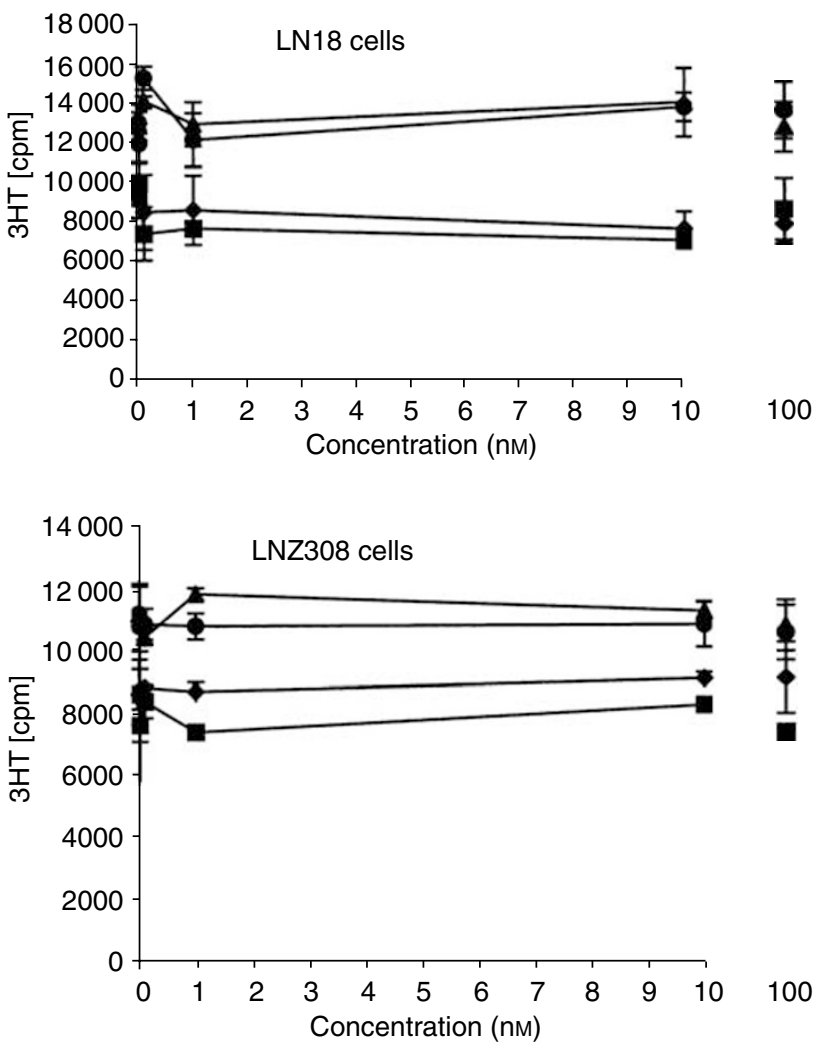

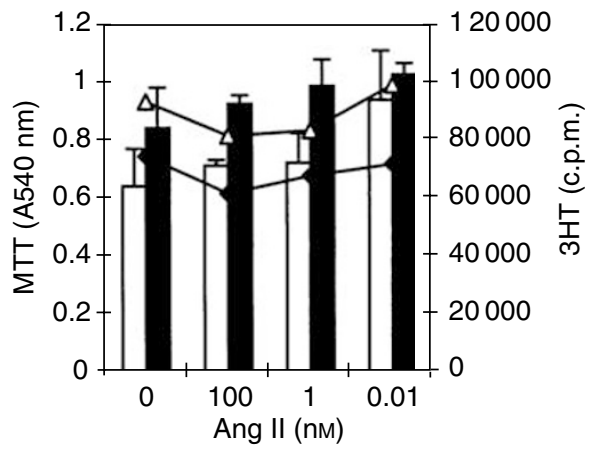

Figure 8 Angiotensinogen, tetradecapeptide renin substrate (Ang | | 4). Ang I, Ang || or Ang III do not modulate glioblastoma cell growth. (A) Left panel: Confluent cultures of LNI 8 and LNZ308 cells were deprived of FCS for $24 \mathrm{~h}$, then exposed for $48 \mathrm{~h}$ in the absence of FCS either to I-I0\% of AGT-

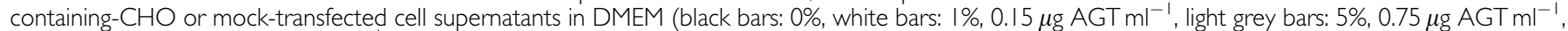
dark grey bars: $10 \%, 1.5 \mu \mathrm{g} \mathrm{AGT} \mathrm{ml}{ }^{-1}$ ). Right panel: Confluent cultures of LNI 8 and LNZ308 cells were deprived of FCS for $24 \mathrm{~h}$, then either exposed for $7 \mathrm{~h}$ to $10^{-7}, 10^{-9}$ or $10^{-11} \mathrm{M}$ Ang II, and thymidine incorporation was performed for $2 \mathrm{~h}$ to determine DNA synthesis $\left({ }^{3} \mathrm{HT} ; \bullet: L N I 8 ; \triangle:\right.$ LNZ308) or exposed for $24 \mathrm{~h}$ to $10^{-11}, 10^{-9}$ or $10^{-7} \mathrm{M}$ Ang $\mathrm{II}$, and MTT reduction was performed to determine the number of metabolically active viable cells (MTT; white bars: LNI8; grey bars: LNZ308). Means \pm s.d. were calculated. (B) LNI 8 and LNZ308 cells were grown for $24 \mathrm{~h}$ to half-confluence in the presence of FCS, then deprived of FCS for $24 \mathrm{~h}$, and exposed for another $24 \mathrm{~h}$ in the absence of FCS to increasing concentration [0 - $100 \mathrm{nM}$ ] of either tetradecapeptide renin substrate $\left(\right.$ Ang | - |4) $(\bullet)$, Ang I $(\mathbf{\square})$, Ang II $(\mathbf{\Delta})$, or Ang III $(\mathbf{O})$ for $24 \mathrm{~h}$. Thymidine $\left({ }^{3} \mathrm{HT}\right)$ incorporation was performed during the last two hours to determine DNA synthesis $\left({ }^{3} \mathrm{HT}\right)$. Means \pm s.d. were calculated.

\section{ACKNOWLEDGEMENTS}

We would like to thank Mrs S Gros, R Bovey, P Fioroni, MT Morin for excellent technical assistance, Mrs MF Hamou and AC Diserens, Neurosurgery Division, CHUV, Lausanne, for providing the cystic fluids and the glioblastoma cell lines, and Dr F Pinet for helpful information. This work was supported by grants from the Swiss League and Research against Cancer (SKL 353-9-1996, KFS 947-09-1999 and KFS 1070-09-2000), the Swiss Society for Multiple Sclerosis and the Swiss National Foundation for Scientific Research (grant 3200-064907.01).

\section{REFERENCES}

Achard JM, Fournier A, Mazouz H, Caride VJ, Penar PL, Fernandez LA (2001) Protection against ischemia: a physiological function of the renin-angiotensin system. Biochem Pharm 62: 261-271
Ariza A, Fernandez LA, Inagami T, Kim JH, Manuelidis EE (1988) Renin in glioblastoma multiform and its role in neovascularization. Am J Clin Pathol 90: 437 - 441 
Baldwin ET, Bhat TN, Gulnik S, Hosur MV, Sowder RC, Cachau RE, Collins J, Silva AM, Erikson JW (1993) Crystal structures of native and inhibited forms of human cathepsin D: implications for lysosomal targeting and drug design. Proc Natl Acad Sci USA 90: 6796-6800

Berry C, Touyz R, Dominiczak AF, Webb RC, Johns DG (2001) Angiotensin receptors: signaling, vascular pathophysiology, and interactions with ceramide. Am J Physiol 281: $\mathrm{H} 2337-\mathrm{H} 2365$

Breu V, Maerki HP, Vieira E, Wostl W (2000) Preparation of piperidine derivatives as renin inhibitors. PCT Int Appl, 70pp (WO $0064873 \mathrm{A1}$ )

Célérier J, Cruz A, Lamandé N, Gasc JM, Corvol P (2002) Angiotensinogen and its cleaved derivatives inhibit angiogenesis. Hypertension 39: $224-228$

Célérier J, Schmid G, Le Caer JP, Gimenez-Roqueplo AP, Bur D, Friedlein A, Langen H, Corvol P, Jeunemaitre X (2000) Characterization of a human angiotensinogen cleaved in its reactive center loop by a proteolytic activity from Chinese hamster ovary cells. J Biol Chem 275: 10648-10654

Deinum J, Derkx FH, Schalekamp MA (1998) Probing epitopes on human prorenin during its proteolytic and non-proteolytic activation. Biochim Biophys Acta 1388: 386-396

De Paepe B, Verstraeten VLMR, De Potter CR, Vakaet LAML, Bullock GR (2001) Growth stimulatory angiotensin II type-1 receptor in upregulated in breast hyperplasia and in situ carcinoma but not in invasive carcinoma. Histochem Cell Biol 116: 247-254

Diserens AC, de Tribollet N, Martin-Achard A, Gaide AC, Schnegg JF, Carrel S (1981) Characterization of an established human malignan glioma cell line: LN18. Acta Neuropathol 53: 21-28

Egidy G, Peduto Eberl L, Valdenaire O, Irmler M, Majdi R, Diserens AC, Fontana A, Janzer RC, Pinet F, Juillerat-Jeanneret L (2000) The endothelin system in human glioblastoma. Lab Invest 80: 1681-1689

Fischli W, Clozel JP, el Amrani K, Wostl W, Neidhart W, Stadler H, Branca Q (1991) Ro 42-5892 is a potent orally active renin inhibitor in primates. Hypertension 18: 22-31

Galen FX, Devaux C, Atlas S, Guyenne T, Ménard J, Corvol P, Simon D, Cazaubon C, Richer P, Badouaille G, Richaud JP, Gros P, Pau B (1984) New monoclonal antibodies directed against human renin. Powerful tools for the investigation of the renin system. J Clin Invest 74: 723-735

Güller R, Binggeli A, Breu V, Bur D, Fischli W, Hirth G, Jenny C, Kansy M, Montavon F, Müller M, Oefner C, Stadler H, Vieira E, Wilhelm M, Wostl W, Märki HP (1999) Piperidine-renin inhibitors: compounds with improved physicochemical properties. Bioorg Med Chem Lett 9: $1403-1408$

Hirasawa K, Sato Y, Hosoda Y, Yamamoto T, Hanai H (2002) Immunohistochemical localization of angiotensin II receptor and local renin-angiotensin system in human colonic mucosa. J Histochem Cytochem 50: 275-282

Humpel C, Lippoldt A, Strömberg I, Bygdeman M, Wagner J, Hilgenfeldt U, Ganten D, Fuxe K, Olson L (1994) Human angiotensinogen is highly expressed in human cortical grafts. Glia 10: 186-192

Inwang ER, Puddefoot JR, Brown CL, Goode AW, Marsigliante S, Ho MM, Payne JG, Vinson GP (1997) Angiotensin II type 1 receptor expression in human breast tissue. Br J Cancer 75: 1279-1283

Juillerat-Jeanneret L (1993) Modulation of proteolytic activity in tissues following chronic inhibition of angiotensin converting enzyme. Biochem Pharm 45: $1447-1454$

Juillerat-Jeanneret L, Lohm S, Hamou MF, Pinet F (2000) Regulation of aminopeptidase $\mathrm{A}$ in human brain tumor vasculature: evidence for a role of transforming growth factor- $\beta$. Lab Invest 80: 973-980

Kakinuma Y, Hama H, Sugiyama F, Goto K, Murakami K, Fukamizu A (1997) Anti-apoptotic action of angiotensin fragments to neuronal cells from angiotensinogen knock-out mice. Neurosci Lett 232: 167-170

Lee-Kirch MA, Gaudet F, Cardoso MC, Lindpaintner K (1999) Distinct renin isoforms generated by tissue-specific transcription initiation and alternative splicing. Circ Res 84: 240-246
Lever AF, Hole DJ, Gillis CR, McCallum IR, MacKinnon PL, Meredith PL, Murray LS, Reid JL, Robertson JW (1998) Do inhibitors of angiotensin-Iconverting enzyme protects against risk of cancer? Lancet 352: $179-184$

Maerki HP, Binggeli A, Bittner B, Bohner-Lang V, Breu V, Bur D, Coassolo PH, Clozel JP, D’Arcy A, Doebeli H, Fischli W, Funk CH, Foricher J, Giller T, Gruninger F, Guenzi A, Guller R, Hartung T, Hirth G, Jenny CH, Kansy M, Klinkhammer U, Lave T, Lohri B, Luft FC, Mervaala EM, Muller DN, Muller M, Montavon F, Oefner CH, Qiu C, Reichel A, Sanwald-Ducray P, Scalone M, Schleimer M, Schmid R, Stadler H, Treiber A, Valdenaire O, Vieira E, Waldmeier P, Wiegand-Chou $\mathrm{R}$, Wilhelm M, Wostl W, Zell M, Zell R (2001) Piperidine renin inhibitors: from leads to drug candidates. Il Farmaco 56: 21-27

Milsted A, Barna BP, Ransohoff RM, Brosnihan KB, Ferrario CM (1990) Astrocyte cultures derived from human brain tissue express angiotensinogen mRNA. Proc Natl Acad Sci USA 87: 5720-5723

Morimoto S, Cassell MD, Sigmund CD (2002) Glia- and neuron-specific expression of the renin-angiotensin system in brain alters blood pressure, water intake, and salt preference. J Biol Chem 277: $33235-33241$

Nakagawa T, Kubota T, Kabuto M, Kodera T (1995) Captopril inhibits glioma cell invasion in vitro: involvement of matrix metalloproteinases. Anticancer Res 15: 1985-1989

Nguyen G, Delarue F, Berrou J, Rondeau E, Sraer JD (1996) Specific receptor binding of renin on human mesangial cells in culture increases plasminogen activator inhibitor-1 antigen. Kidney Int 50: 1897-1903

Nguyen G, Delarue F, Burcklé C, Bouzhir L, Giller T, Sraer JD (2002) Pivotal role of the renin/prorenin receptor in angiotensin II production and cellular response to renin. J Clin Invest 109: 1417-1427

Oefner C, Binggeli A, Breu V, Bur D, Clozel JP, D’Arcy A, Dorn A, Fischli W, Grüninger F, Güller R, Hirth G, Märki HP, Mathews S, Müller M, Ridley RG, Stadler H, Vieira E, Wilhelm M, Winkler FK, Wostl W (1999) Renin inhibition by substituted piperidines: a novel paradigm for the inhibition of monomeric aspartic proteinases? Chem Biol 6 $127-131$

Peduto Eberl L, Valdenaire O, SaintGiorgio V, Jeannin JF, JuilleratJeanneret L (2000) Endothelin receptor blockade potentiates FasLinduced apoptosis in rat colon carcinoma cells. Int J Cancer 86: 182-187

Reddy MK, Baskaran K, Molteni A (1995) Inhibitors of angiotensinconverting enzyme modulate mitosis and gene expression in pancreatic cancer cells. Proc Natl Acad Sci USA 210: 221-226

Reid WA, Valler MJ, Kay J (1986) Immunolocalization of cathepsin D in normal and neoplastic human tissues. J Clin Pathol 39: 1323-1330

Rivera E, Arrieta O, Guevara P, Duarte-Rojo A, Sotelo J (2001) AT1 receptor is present in glioma cells, its blockage reduces the growth of rat glioma. Br J Cancer 85: 1396 - 1399

Sibony M, Commo F, Callard P, Gasc JM (1995) Enhancement of mRNA in situ hybridization signal by microwave heating. Lab Invest 73: 586-591

Sinn PL, Sigmund CD (2000) Identification of three human renin mRNA isoforms from alternative tissue-specific transcriptional initiation. Physiol Genomics 3: 25-31

Tahmasebi M, Puddefoot JR, Inwang ER, Goode AW, Carpenter R, Vinson GP (1998) Transcription of the prorenin gene in normal and diseased breast. Eur J Cancer 34: 1777 - 1782

Takahashi S, Miura R, Miyake Y (1985) A study of renin binding protein (RnBP) in the human kidney. J Biochem 97: 671-677

Vieira E, Binggeli A, Breu V, Bur D, Fischli W, Güller R, Hirth G, Märki HP, Müller M, Oefner C, Scalone M, Stadler H, Wilhelm M, Wostl W (1999) Substituted piperidines. Highly potent renin inhibitors due to induced fit adaptation of the active site. Bioorg Med Chem Lett 9: $1397-1402$

Yoshiji H, Kuriyama S, Fukui H (2002) Perindopril: possible use in cancer therapy. Anti-cancer drugs 13: 221-228 